\title{
Population Ecology of the Fiddler Crab Uca spp. in Punta, Baybay City, Leyte
}

\author{
Kalvin Jay G. Boregon and Julissah C. Evangelio \\ Department of Biological Sciences, Visayas State University, Visca, Baybay City, \\ Leyte, Philippines
}

\begin{abstract}
A study on the population of the fiddler crabs, Uca spp. was conducted to determine their abundance, density, sex ratio, frequency and distribution pattern in the mangrove area of Punta, Baybay City, Leyte. A total of 126 individual fiddler crabs belonging to three different species were collected in a $6,000 \mathrm{~m}^{2}$ mangrove area from September to December, 2013. The three fiddler crab species were Uca perplexa, U. triangularis, and U. crassipes. Uca perplexa had the highest density which occurred only in the landward zone while $U$. triangularis occurred in all three zones (seaward, middle and landward). The sex ratio of $U$. perplexa population did not deviate from the typical 1:1 ratio while $U$. triangularis did. In terms of their mean size, males of $U$. perplexa were significantly different from females while $U$. triangularis showed no significant size difference between males and females. Both $U$. perplexa and $U$. triangularis populations had non-normal overall size frequency distributions which were aggregately distributed. Distribution of U. perplexa population appeared to be influenced by substrate type-while $U$. triangularis was not affected by this parameter.
\end{abstract}

Keywords: Uca perplexa, Uca triangularis, sex ratio, size frequency distribution, sediment

\section{INTRODUCTION}

Fiddler crabs are ever-present brachyuran element in the muddy, muddy-sand or sandy-mud intertidal zone in sheltered, estuarine and mangrove areas throughout tropical and subtropical regions of the world (Johnson, 2003). Together with mollusks, they behave as the chief supplier of macro-faunal biomass of mangrove ecosystem (Wolff et al., 2000). Their diversity and adaptation to different biotopes are regarded to be correlated with modifications of their own ecology, behavior, physiology, and morphology (Takeda and Murai, 2003). Uca spp. have important ecological effects on mangrove communities. These crustaceans serve as ecological engineers that alter the physical, chemical, and biological state of these communities. They physically modify these areas through their burrow construction in the sediment. These burrows are used as a refuge when environmental conditions at the sediment surface are intolerable (Thongtham and Kristensen, 2003). Chemically, these burrows increase the volume of the sediment which contains oxidized $\mathrm{Fe}^{3+}$ (Kristensen and Holmer, 2001). In the biological aspect, their excavation activities allow the relocation of microphytobenthic and macrophyte detritus into burrows, thereby enhancing the efficiency of microbial decomposition in subsurface sediments (Botto and Iribarne, 2000). They are also good environmental indicators as they are sensitive to environmental contaminants like sewage and oil spill (Bartolini et al., 2009; Culbertson et al., 2007). Fiddler crab Uca annulipes exhibits altered feeding behavior and U. pugnax with lowered population density when exposed to sewage and oil spill, respectively. In marshes, 
fiddler crabs are unevenly distributed and vary in density where movement of water, oxidants, and other materials are likely to vary spatially, resulting in variation of plant production (Gribsholt et al., 2003). Hence, it is also possible that their presence may influence the spatial distribution or zonation in mangrove forests. Studies focusing on the populations of fiddler crabs have increased through time (Litulo, 2005a, b). These provide information about their size frequency distributions, density, sex ratio, spatial dispersion, juvenile recruitment, and reproduction. However, these studies were only carried out in subtropical areas (e.g. Gulf of Mexico, Mouton and Felder, 1995; Marchiquita Lagoon, Spivak et al., 1991) and lesser were done in the tropics. There are already 97 species of Uca that have been identified and described (Rosenberg, 2001) and at least 30 species are endemic to the Pacific coasts of Central and northern South America. A significant number of species are also found throughout the Indo-West Pacific region (Levinton et al., 1996). Currently, there is not much studies conducted in the Philippines on the population ecology of $U_{c a}$ spp. Particularly, no previous work has been done on the population structure of fiddler crabs in the municipality of Baybay, hence, this study. This information is important in shaping mangrove communities. It is important for the local people to know and understand the ecological value of these crabs because this can be a very useful tool in formulating a conservation program for them. At present, there is already a decline in populations of individual fiddler crab species due to high human interference and pollution load (Talapatra et al., 2014).

\section{MATERIALS AND METHODS}

\section{Site Description}

The field work took place in Punta, Baybay City, Leyte which is 11 kilometers away from the city proper of Baybay. Punta has 398, 800 mangrove stands (Montes et al., 2009) traversing Sitio Lawis to the Center of the barangay. The climate is type IV; temperature ranges from $22^{\circ} \mathrm{C}$ to $32^{\circ} \mathrm{C}$ and the average annual rainfall is around $3,000 \mathrm{~mm}$ (http://www.swm4lgus.net/partner-lgu/BaybayLeyte.php). Two sites were established during the preliminary survey within the barangay with site $1\left(10^{\circ} 38.483^{\prime} \mathrm{N}, 124^{\circ} 46.642^{\prime} \mathrm{E}\right)$ being close to the residences in Sitio Lawis and site $2\left(10^{\circ} 38.107^{\prime} \mathrm{N}, 124^{\circ} 46.603^{\prime} \mathrm{E}\right)$ located at the center of the barangay. Both sites were composed of sandy substrates. The seaward and middleward zones of site 1 were dominated with Avicennia lanata. On the other hand, the seaward, middleward, and landward zones of site 2 were dominated with Aegiceras floridum, Sonneratia caseolaris and Avicennia lanata, respectively.

\section{Sampling Methods}

A $50 \mathrm{~m}$ transect was laid in each site. The first transect laid during the first sampling was considered as the reference point for the next random laying of transects in the succeeding samplings. Randomization was done by picking random number (i.e. distance from the reference transect in meters) and random direction (i.e. left or right side from the reference). Six $1 \mathrm{~m}$ x $1 \mathrm{~m}$ plots that were 10 meters apart were established in each transect (Fig. 1). In each plot, 3 Sampling replicates were excavated with a $30 \mathrm{~cm}$ x $30 \mathrm{~cm} \times 30 \mathrm{~cm}$ box corer following the method of Bezerra and Cascon (2007). Most fiddler crabs burrow up to this depth, particularly U. annulipes, a closely related species of U. perplexa (Litulo, 2005a). Plots were sampled once a month during the full moon from September to December 2013. Transects were laid from the seaward to landward zones.

\section{Datagathered}

All fiddler crabs present in each box corer were collected and placed in properly 
labeled containers. The crabs were brought to the preparation room of the Department of Biological Sciences for species identification and length-weight measurement. All the collected species were sorted out, counted and the sex of individual species was determined. Males were determined through the presence of an enlarged major cheliped, a feature absent in females. Each species was identified using the guide by Crane (1975) and the website http://www.fiddlercrab.info/uca_systematics.html. Their weight (g) was determined using a digital top loading balance while carapace length and width $(\mathrm{mm})$ were measured using Vernier caliper. For the mangrove vegetation, dominant mangrove species per zone were noted in each site.

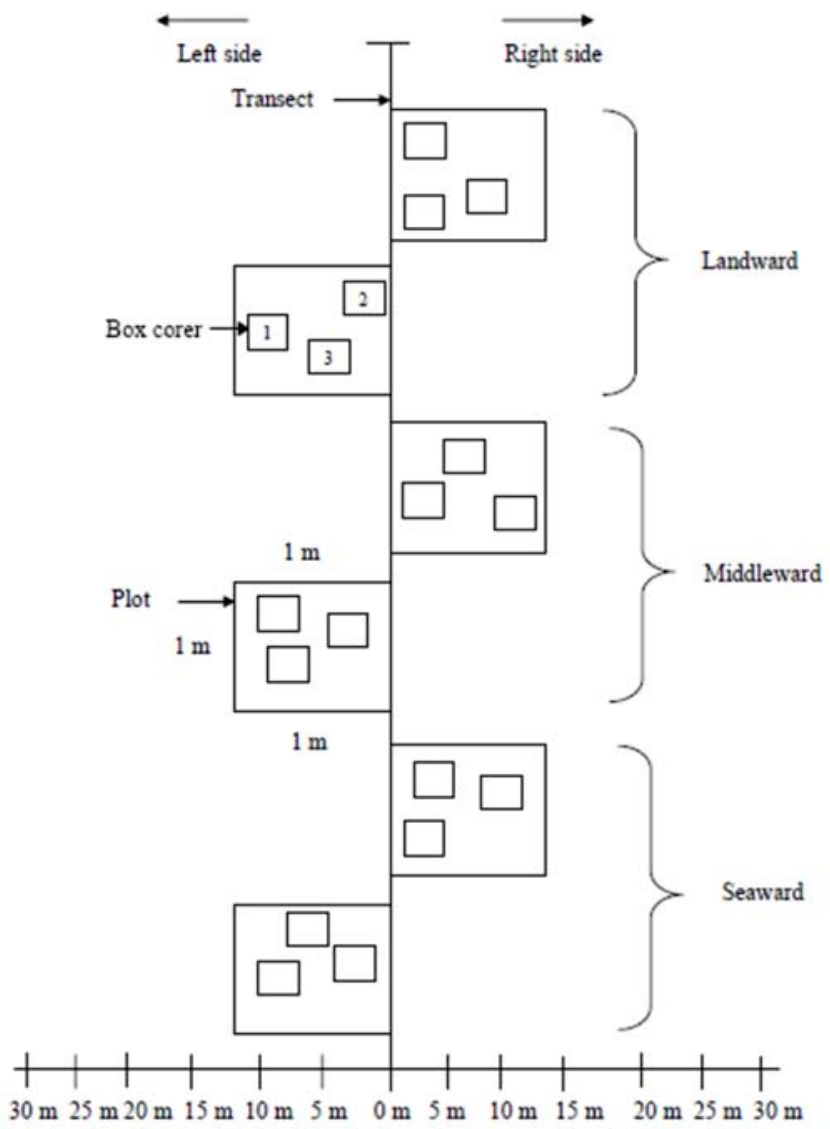

Figure 1. Schematic Diagram of Sampling Method

\section{EcologicalParameters}

Soil samples from six (6) sampling points were collected per zone. The samples were collected about $30 \mathrm{~cm}$ deep using a spade and each sample was placed in a plastic bag container. These samples were analyzed for soil texture, percent organic matter, and carbon. Analyses were done at the Central Analytical Services Laboratory of the PhilRootcrops Complex, Visayas State University, Visca, Baybay City, Leyte. Water salinity, temperature, and $\mathrm{pH}$ were measured using a refractometer, thermometer, and $\mathrm{pH}$ paper, respectively. 


\section{Data Analyses}

The population size structure was analyzed as a function of the size frequency distribution of all males and females collected during the study period. Relative abundance was determined by counting all the fiddler crabs that were excavated in each plot by the box corer per transect. Population density was measured by determining the average number of fiddler crabs per cubic meter. Differences in relative abundance and density of fiddler crabs (pooled) in each site per zone were compared following the One-Way Analysis of Variance (ANOVA). Relative abundance and density between two different sites were also computed regardless of species composition. The sex ratio per species was tested for deviation from the typical 1:1 ratio using the Chi-square test $\left(x^{2}\right)$ for goodness-of-fit. The mean size of males and females per species were compared using the One-Way Analysis of Variance (ANOVA) to determine sexual dimorphism. The overall size frequency distribution per species was tested for normality with Kolmogorov-Smirnov test in SPSS software. The distribution pattern of $U_{c a}$ spp. per transect was determined using Morisita's index. The ecological parameters per zone were correlated to the population of fiddler crabs using Pearson Correlation in SPSS Software.

\section{RESULTS AND DISCUSSION}

\section{Taxonomic Description of Uca spp. in Punta, Baybay City, Leyte}

A total of three fiddler crab species were identified at the two sampling sites of Punta mangrove area (Fig. 2). These were Uca perplexa (Fig. 2A, B and C), Uca triangularis (Fig. 2D, $\mathrm{E}$ and $\mathrm{F}$ ), and $\mathrm{Uca}_{c a}$ crassipes (Fig. $2 \mathrm{G}, \mathrm{H}$ and $\mathrm{I}$ ). Individuals of $U$. perplexa have a homogeneously pale colored carapace. The outer pollex of the major cheliped in males has a distinct row of minute tubercles. The distribution of tubercles makes the outer pollex distinctly rough in most individuals. The dactyl is arched only in distal fifth, starting at beginning of the strong and downward curve. Proximally, its upper margin is virtually straight and almost parallel to edge of gape (Crane, 1975) (Fig. 2C). U. triangularis, the second species, has wholly orange, yellow, or white carapace colors. The markings on the carapace consisted of 2 to 5 transverse pale bands, usually blue and often broken (Fig. 2D and E). Both the pollex and dactyl are moderately slender. Pollex is arched throughout with its ventral margin notably convex. The outer surface of dactyl is convex (Fig. 2F). The third fiddler crab species is $U$. crassipes (Fig.2G and H). Individuals have carapace mainly colored with black or red, with blue blotches. The carapace has strongly obliqued orbits. Their vertical lateral margins are strong, reaching even to the antero-lateral margins. The pollex base, of the major cheliped (Fig. 2I), has an outside small and roughly triangular depression. There is no enlarged and triangular tooth present subdistally on dactyl (Fig. 2I).

\section{Population Structure and Size}

In the $1,800 \mathrm{~m}^{3}$ mangrove area sampled, a total of 126 fiddler crab individuals (pooled) that belong to three different species were collected throughout the duration of the study from September to December, 2013. Among the three species identified, U.perplexa and $U$. triangularis were observed to be markedly abundant while $U$. crassipes was rarely encountered during the sampling period (Fig. 3).There were only $2.78 \mathrm{~m}^{-3} U$. crassipes that were found throughout the study period. This may suggest that the sampled areas were not the preferred habitat of the said species. Since only very few individuals of $U$. crassipes were found, the succeeding analyses were focused more on the two most abundant species of the two different sites. $U$. perplexa appeared to dominate the landward zone of site 1 while U. triangularis dominated the seaward zone of site 2 (Fig. 4). The two species seem to have a distinct habitat preference wherein $U$. perplexa species would likely thrive in sandy 
substrates of open areas while $U$. triangularis also preferred sandy substrates but in wellvegetated and shaded areas. This trend can be validated by the sediment characteristics of the two sampling sites as well as their vegetative characteristics. Figure 4 shows the average density of the two dominant species in each site per zone. In site 1 individuals of U. perplexa had the highest density $\left(23.89 \mathrm{~m}^{-3}\right)$ which was found only in the landward zone while $U$. triangularis individuals were encountered in the middleward and seaward zones. Moreover, U. triangularis were observed throughout the different zones in site 2 having the highest density in the seaward zone $\left(21.11 \mathrm{~m}^{-3}\right)$ followed by the middle zone $\left(15.56 \mathrm{~m}^{-3}\right)$ while the density in the landward zone was only $4.44 \mathrm{~m}^{-3}$ (Fig. 4). The abundance of fiddler crabs varied significantly among the different zones $(p$-value $\leq 0.05)$ in site 1 but not in site 2 . This is because U. perplexa which dominated site 1 was only found in the landward zone suggesting that this area is preferred by the organism. The landward zone had a sandy substrate and had no mangrove stands and other vegetation (Fig. 8). On the other hand, the occurrence of $U$. triangularis in all three zones could indicate that it can occur in a variety of substratum. These two species did not coexist because $U$. perplexa preferred unvegetated area to avoid harassment and predation by sesarmid crabs, which usually thrive along the bark and roots of mangrove species (Warren and Underwood, 1986). On the other hand, $U$. triangularis preferred the vegetated parts because they have lower tolerance to high temperatures as compared to U. perplexa (Mokhtari et. al., 2015). This species could have used the vegetation as a shelter against heat.

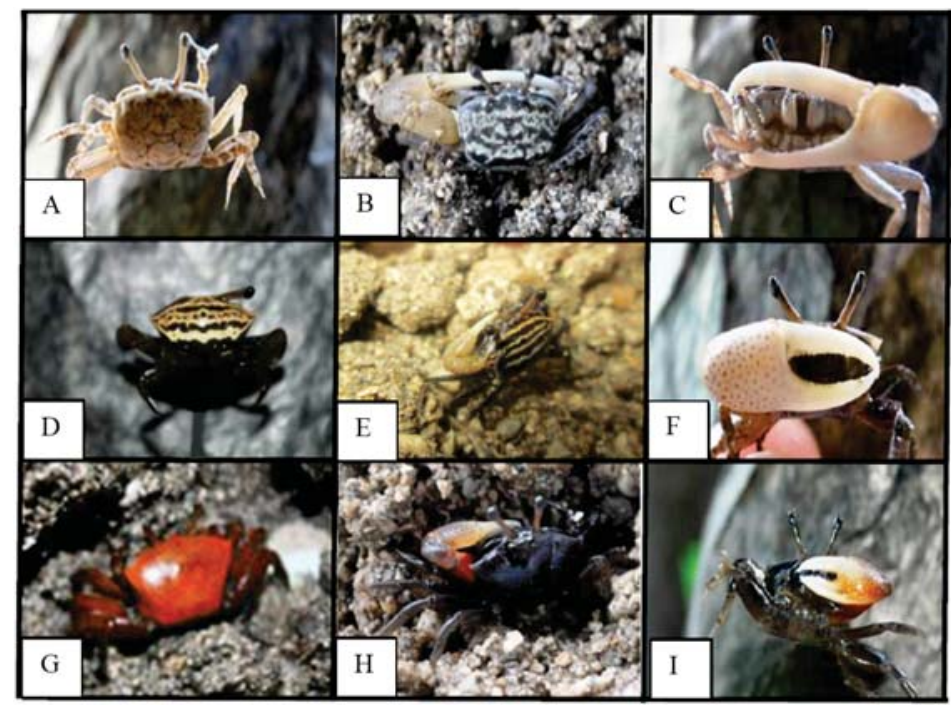

Figure 2. Fiddler crab species from Punta mangrove area: A. Uca perplexa (female), B. U.perplexa (male), C. U. perplexa male (major cheliped), D. U. triangularis (female), E. U. triangularis (male), F. U. triangularis male (major cheliped), G. U. crassipes (female), H.U. crassipes (male), I. U. crassipes male (major cheliped).

Sexratio

Table 1 shows the total number of male and female fiddler crabs, their sex ratio and frequency. During the study, U. perplexa had 23 males (53.59\%) and 20 females $(39.53 \%)$ whereas U. triangularis had 28 males $(37.84 \%)$ and 46 females $(62.16 \%)$. There were 3 ovigerous $U$. perplexa females $(6.98 \%)$ found which might indicate breeding season. Although there were only three egg-carrying females, their sizes ranged from $8 \mathrm{~mm}$ 14.3mm carapace width (CW), which lies within the largest size classes (Fig. 5A). Bezerra and Cascon (2007) reported similar size range $(7-10 \mathrm{~mm})$ for ovigerous females of $U$. 
leptodactyla, a related species of U.perplexa. Also, most of the sizes of U.perplexa during this period were observed to be abundant in the largest size class, which possibly suggests their sexual maturity. However, the low number of collected egg-carrying females conforms to the study of Aciole et al., (2000) who found only 1 egg-carrying female among the 351 collected females of U. leptodactyla, a related species of U.perplexa, in a one-year period.

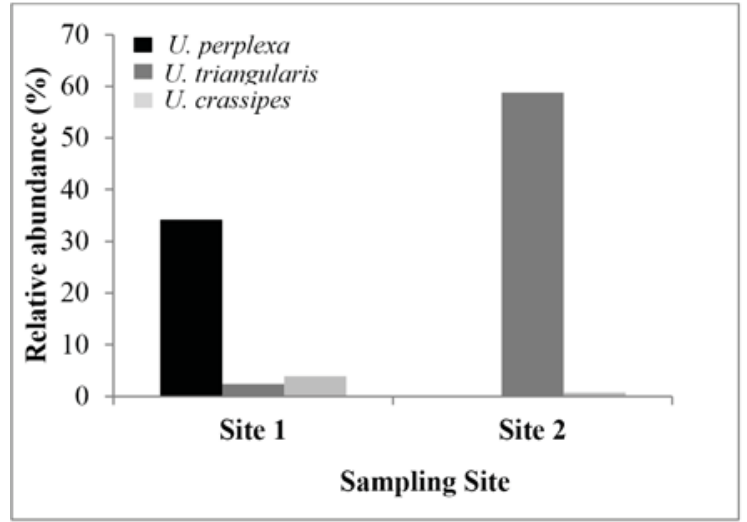

Figure 3. Relative abundance of the three fiddler crab species encountered in Punta, Baybay, Leyte.

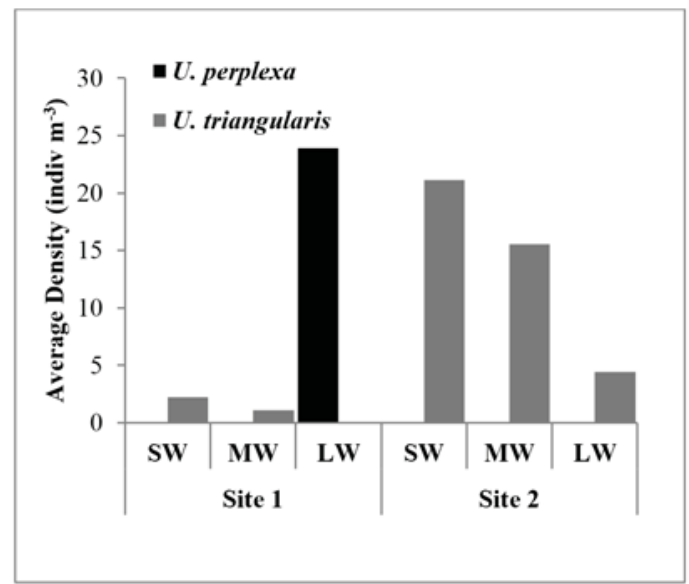

Figure 4. Average density $\left(\mathrm{m}^{-3}\right)$ of $U$.perplexa and $U$. triangularis individuals among different zones at two different sites. SW: seaward; MW: middleward; LW: landward.

The collected ovigerous females of $U$. perplexa were observed to hide deeper than most males did. According to Litulo (2005a), egg-carrying females are not easy to collect as they hide deeper inside the burrows to incubate the eggs. Litulo (2005a, b) also found ovigerous females of $U$. annulipes to inhabit burrows at depths of about $30 \mathrm{~cm}$. The low number of observed egg-carrying $U$. perplexa females could also be brought about by the dry condition during the sampling periods. The findings of this study corroborates with the findings of Mokhtari et al., (2008) who found that the reproductive activity of Uca annulipes is restricted to warm seasons. On the other hand, no ovigerous females were observed in $U$. triangularis although females comprised most of the population (Table 1). It might be that reproduction period of this species is limited to certain periods during the year just like $U$. thayeri which reproduces only from January to June (Bezerra and Cascon, 2007). It was also noted from the size frequency distribution that sizes of this particular species are concentrated to larger size class (Fig. 5B). The sex ratio in U.perplexa shows no significant 
differences between the proportions of males and females $\left(X^{2}=0.209\right.$, with $p$-value $\geq$ 0.05). This means that the male and female population of this species does not differ significantly. The result agrees with Litulo (2005a) who indicated that there is no significant deviation from the 1:1 sex ratio in $U$. annulipes population, a closely related species of $U$. perplexa, as they are of the same subgenus Uca lactea. However, males and females of Uca triangularis deviate from the typical 1:1 sex ratio $\left(\mathrm{X}^{2}=4.378\right.$, with $\mathrm{p}$-value $\left.\leq 0.05\right)$. This deviation might have resulted from the sexual differences in mortality rates of the two different sexes (Johnson, 2003). Males are more vulnerable to predation because their enlarged claw may inhibit rapid escape from predators (Montague, 1980). Also, their claw muscle, with an added nutritional content, makes them more profitable as prey (Zwarts and Blomert, 1990 as cited by Koga et al., 2001). There is differential predation on males and females as there are predators that feed on Uca (Cannicci et al., 1996 as cited by Nobbs, 1999). Populations that present a 1:1 sex ratio live in constant environments and randomly mate (Geisel, 1972; Fisher, 1930 as cited by Bezerra and Cascon, 2007). This was evident for $U$. perplexa only, wherein members were specifically confined to a particular site and at a distinct zone.

Table 1. Total number and sex ratio of individuals collected monthly in Punta, Baybay City, Leyte.

\begin{tabular}{|c|c|c|c|c|c|c|c|c|c|c|c|}
\hline \multirow{2}{*}{$\begin{array}{l}\text { Fiddler crab } \\
\text { species }\end{array}$} & \multirow{2}{*}{ Month } & \multirow{2}{*}{ Males } & \multirow{2}{*}{ s $\%$} & \multicolumn{4}{|c|}{ Females } & \multirow[b]{2}{*}{$\begin{array}{c}\text { Females } \\
\text { Total }\end{array}$} & \multirow{2}{*}{$\begin{array}{c}\begin{array}{c}\text { Males and } \\
\text { Females }\end{array} \\
\text { Total }\end{array}$} & \multirow{2}{*}{ Sex ratio } & \multirow{2}{*}{ Frequency } \\
\hline & & & & Ovigerous & $\%$ & $\begin{array}{c}\text { Non- } \\
\text { ovigerous }\end{array}$ & $\%$ & & & & \\
\hline \multirow{3}{*}{ Uca perplexa } & September & 7 & 46.67 & 3 & 20 & 5 & 33.33 & 8 & 15 & 0.88 & 0.33 \\
\hline & October & 7 & 100.00 & 0 & 0 & 0 & 0 & 0 & 7 & 0 & 0.33 \\
\hline & December & 9 & 42.86 & 0 & 0 & 12 & 57.14 & 12 & 21 & 0.75 & 0.33 \\
\hline \multicolumn{2}{|c|}{ Total } & 23 & 53.59 & & 6.98 & & 39.53 & 20 & 43 & & \\
\hline \multirow{3}{*}{ U. triangularis } & September & 7 & 43.75 & 0 & 0 & 9 & 56.25 & 9 & 16 & 0.78 & 0.83 \\
\hline & October & 6 & 27.27 & 0 & 0 & 16 & 72.72 & 16 & 22 & 0.38 & 1.00 \\
\hline & December & 15 & 41.67 & 0 & 0 & 21 & 58.33 & 21 & 36 & 0.71 & 0.67 \\
\hline \multicolumn{2}{|c|}{ Total } & 28 & 37.84 & & 0 & & 62.16 & 46 & 74 & & \\
\hline
\end{tabular}

\section{Size frequency distribution of individuals}

Males of U. perplexa encompassed the smallest (4-6 mm) and largest (13-15 mm) size class. However, most of them belonged to 10-12 mm size class. Females, on the other hand, belonged to the lower size classes (7-9 $\mathrm{mm}$ and 10-12 mm) (Fig. 5A). The overall size frequency of the population was not normally distributed at $\mathrm{p}$-value $\leq 0.05$. The result agrees with Mokhtari et al., (2008), who found that males of $U$. annulipes also dominate the larger size classes. On the other hand, females of $U$. triangularis were more recurrent from the smallest size class (4-6 mm) until 10-12 mm size class (Fig. 5B). There was also an observed overall non-normal size-frequency distribution for this species. The fiddler crabs also exhibit size variation between male and female which could indicate sexual dimorphism. The mean size of individual male and female crabs for each species collected from the study was also investigated to determine sexual dimorphism. Carapace Width $(\mathrm{CW})$ of $U$.perplexa males ranged from $4 \mathrm{~mm}$ to $11.6 \mathrm{~mm}(\overline{\mathrm{x}}=8.95 \pm 2.17)$ while females ranged from $4.4 \mathrm{~mm}$ to $9.45 \mathrm{~mm}(\overline{\mathrm{x}}=7.33 \pm 1.71)$. Fig. $6 \mathrm{~A}$ shows that $U$. perplexa males attained the highest $(\overline{\mathrm{x}}=10.41 \pm 0.92)$ and lowest $(\overline{\mathrm{x}}=7.13 \pm 1.95)$ mean carapace width in the months of October and December, respectively. Females, on the other hand, achieved their highest $(\overline{\mathrm{x}}=8.59 \pm 1.07)$ mean size in September. Costa et. al., (2006) noted that females of $U$. annulipes become sexually mature when they reach $11.3 \mathrm{~mm} \mathrm{CW}$. Fig. $6 \mathrm{~B}$ shows that males of $U$. triangularis reached the highest $(\overline{\mathrm{x}}=8.04 \pm 1.97)$ and lowest $(\overline{\mathrm{x}}=6.51 \pm 2.18)$ mean sizes during the months of September and December. Females of this species attained the highest $(\overline{\mathrm{x}}=7.01 \pm 1.52)$ mean size in October and the lowest $(\overline{\mathrm{x}}=5.26 \pm 2.25)$ mean size during December. There was a significant difference between the mean size of $U$. 
perplexa males and females (p-value $\leq 0.05)$ suggesting that $U$.perplexa population exhibits sexual dimorphism based on size. According to Johnson (2003), males of fiddler crab populations are generally larger than females. Most male fiddler crabs are usually larger because they concentrate on somatic growth to have greater chances of obtaining females for copulation and of winning intra-specific fights (Litulo, 2005a). On the other hand, females are smaller because they concentrate their energetic budget on gonad development (Johnson, 2003). A significant difference was also observed in their monthly mean sizes (pvalue $\leq 0.05)$ where larger sizes were observed to be concentrated in the months of September and October 2013. On the other hand, the mean size of U. triangularis males was not found to be significantly different to the mean size of females ( $\mathrm{p}$-value $\geq 0.05$ ) suggesting that $\mathrm{CW}$ cannot be used to distinguish a male from a female. However, the monthly mean sizes were significantly different $(p$-value $\leq 0.05$ ) which shows relatively larger sizes in the months of September and October 2013. These months could probably relate to the breeding season for both species.

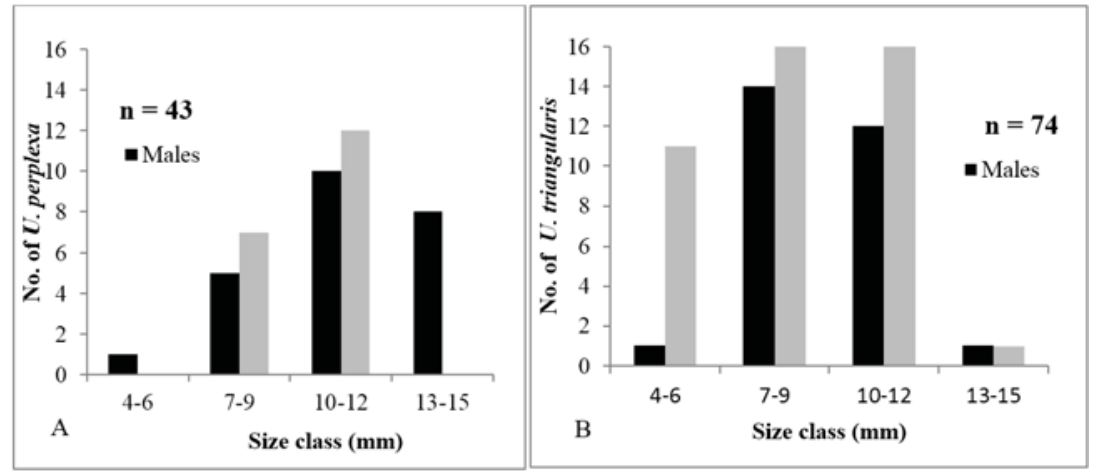

Figure 5. Overall size frequency distribution (A-U. perplexa of site 1, B- U. triangularis of site 2) observed in Punta, Baybay, Leyte from September to December 2013.
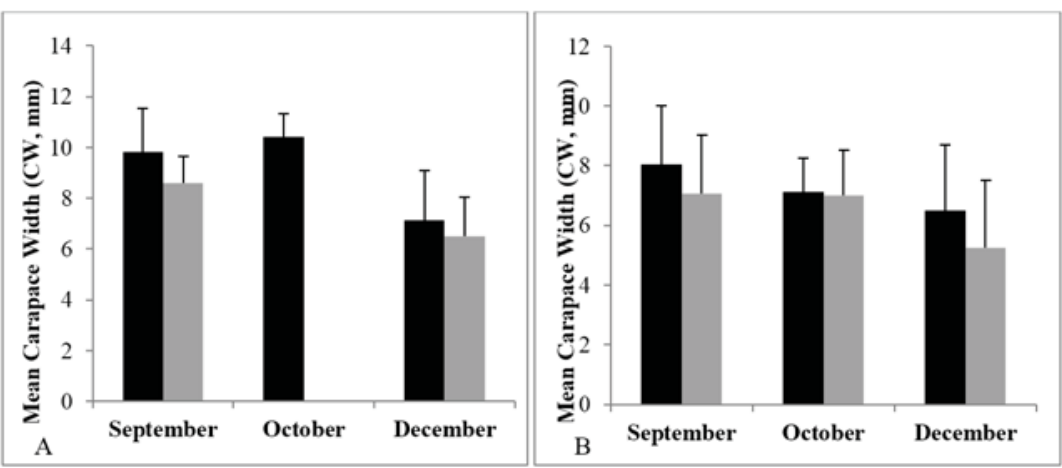

Figure 6. Mean size $\pm \mathrm{SD}$ of individuals (A- U.perplexa, B- U. triangularis) collected in Punta, Baybay City, Leyte from September to December 2013. Black bars: males; gray bars: females (ovigerous and non- ovigerous)

\section{Width-Weight relationship}

The carapace width to weight relationship for both U. perplexa and U. triangularis is shown in Figures 7A and B. Results showed that U. perplexa males had weights that ranged from 0.1 to $0.8 \mathrm{~g}(\overline{\mathrm{x}}=0.39 \pm 0.26 \mathrm{~g})$ while females had 0.01 to $0.39 \mathrm{~g}(\overline{\mathrm{x}}=0.16 \pm 0.11 \mathrm{~g})$. $U$. triangularis males had weights ranging from 0.01 to $0.53 \mathrm{~g}(\overline{\mathrm{x}}=0.17 \pm 0.15 \mathrm{~g})$. Females, of this 
species, ranged from 0.01 to $0.4 \mathrm{~g}(\overline{\mathrm{x}}=0.15 \pm 0.14 \mathrm{~g})$. For both species, smaller sizes showed slower growth in weight. At this stage, the carapace width seemed to increase faster than weight. As the organisms had grown larger, increase in weight became faster than carapace width. There was an observed highly significant correlation $(r=0.88$ for $U$. perplexa; $r=$ 0.69 for $U$. triangularis) between the carapace width and weight in both species. As the carapace width of these two species increased, their individual weights also increased showing a directly proportional relationship.

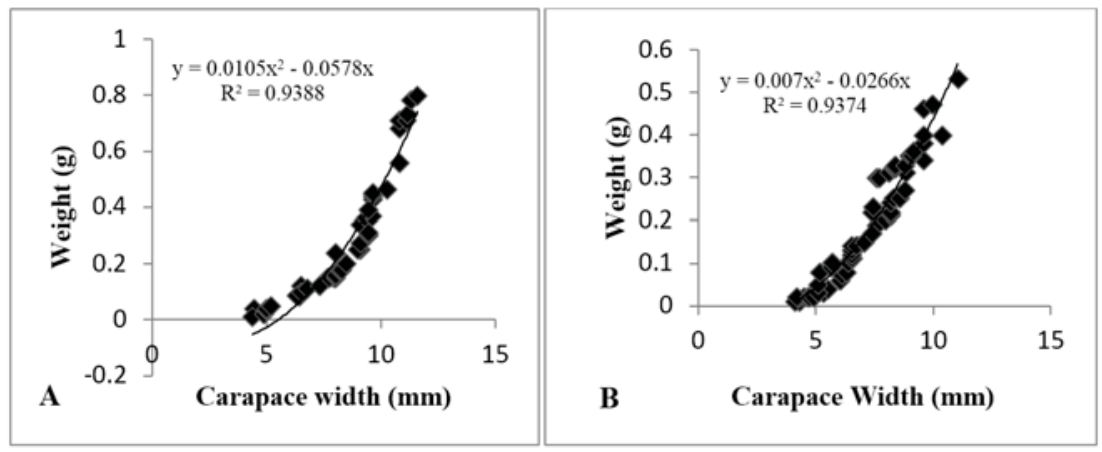

Figure 7. Carapace width-weight relationship of U.perplexa (A) and U. triangularis (B) in Punta, Baybay, Leyte. Best fit trendline are described by a polynomial function order $=2$.

\section{Distribution pattern}

Both $U$. perplexa $(\mathrm{I}=4.51)$ and $U$. triangularis $(\mathrm{I}=1.63)$ were observed to have an aggregate distribution pattern in the mangrove area of site 1 and site 2 , respectively. $U$. perplexa population was only present in the landward zone, and in this zone they were observed to be aggregated. Figures $8 \mathrm{~A}$ and $8 \mathrm{~B}$ show the schematic diagram of the two different sites which may help explain the composition of the two fiddler crab species and their population ecology. Site 1 was dominated with Avicennia lanata in the seaward and middleward zones while the landward zone was unvegetated but inhabited by the locals in the community (Fig. 8A). Results from the soil analyses showed an increase in the percentage of organic carbon (OC) and organic matter (OM) from the landward to the seaward zone. The lower OC and OM can be attributed to the presence of U.perplexa in this zone. It could be suggested that the burrowing activity of crabs, in the landward zone had enhanced oxidation of sediment, thus reducing the organic content (Nielsen et al., 2003 as cited by Mokhtari et al., 2008). An increase in the percent sand toward the seaward zone was also noted. However, the increase is insignificant ( $p$-value $\geq 0.05$ ) which means that this ecological parameter is well-distributed throughout the site. In addition, among the determined substrate attributes, the mean percent sand significantly influenced the density of $U$. perplexa ( $\mathrm{p}$-value $\leq 0.05$ ). It was observed that $U$. perplexa individuals prefer more a substrate with high percent sand than any other substrate types. In site 2, there was an increase in the percent $\mathrm{OC}$ and $\mathrm{OM}$ from the landward zone to the middleward zone (Fig. $8 \mathrm{~B})$. However, a decrease in these components was noticed from the middleward zone toward the seaward zone. The figure also shows the increase in percentage of silt and clay from the landward zone towards the seaward zone. The sediment characteristics of the second site were also not significantly different among the three zones ( $p$-value $>0.05$ ). Furthermore, the density of $U$. triangularis population was also not significantly affected by the percent of organic carbon, organic matter, silt, clay and sand present in the sediment ( $\mathrm{p}$ value $\geq 0.05$ ). Although there was a significant effect of the amount of mean percent sand in the sediment to the density of U. perplexa, it was not only this characteristic that 
influenced the spatial distribution of the population because there was no significant difference in the amount of mean percent sand in the other remaining two zones of the site. Other factors could have caused their limited density in the zone. On the other hand, $U$. triangularis individuals were also in clumped distribution in site 2 . These individuals were present in all of the three zones, unlike the first species which were more confined to the landward zone. However, the sediment characteristics of the site such as the $\%$ organic carbon, $\%$ organic matter, $\%$ silt, $\%$ clay and $\%$ sand were not responsible for the $U$. triangularis spatial distribution in this site. These five (5) characteristics of the sediment did not show significant effects to the density of crabs in each zone at $\alpha=0.05$.

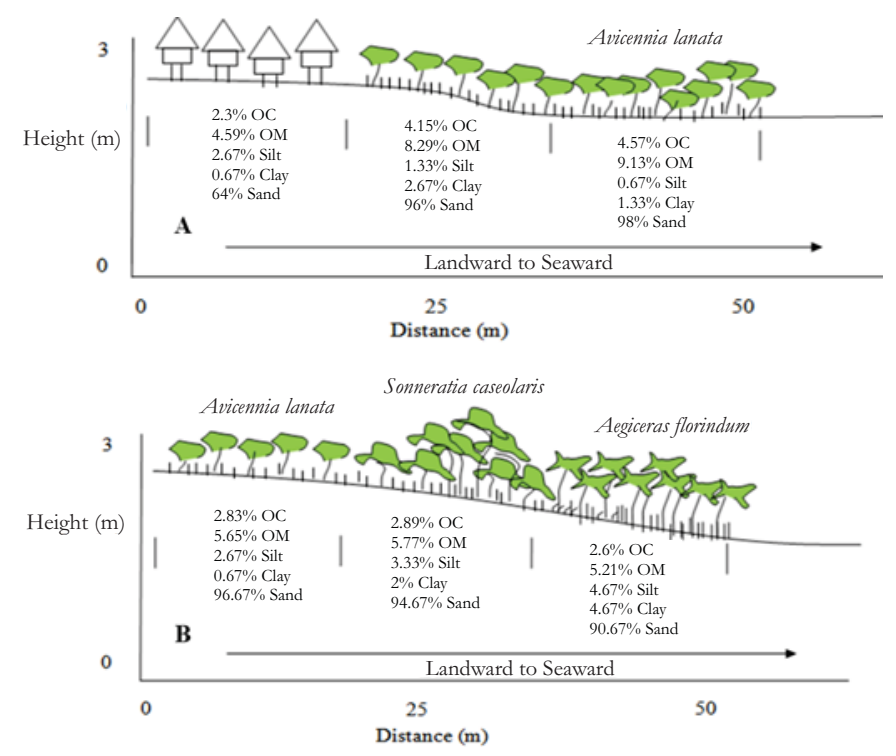

Figure 8. Schematic topographic profiles of the different study sites (A-Site 1, B- Site 2) at Punta, Baybay City, Leyte mangrove area.

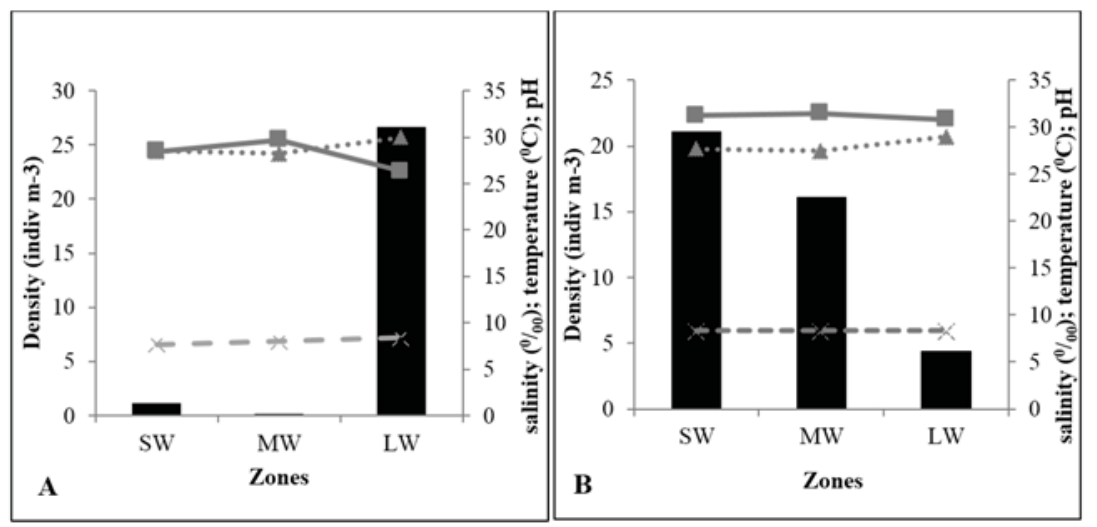

Figure 9. Average salinity, temperature, and $\mathrm{pH}$ plotted against fiddler crab density in Punta, Baybay City, Leyte mangrove from September 2013 to December 2013. A:site 1; B:site 2. SW: seaward;

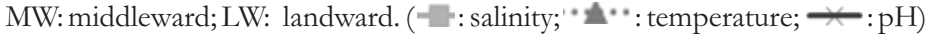

According to Carmona-Suarez and Conde (1996), different factors may act as barriers or boundaries for fiddler crab species and confine them to their habitat. These factors include water salinity, temperature, availability of nutrients, and availability of oxygen (Macintosh, 1982; Bezerra et. al., 2006). This study, however, considered salinity, $\mathrm{pH}$, and 
temperature only as factors aside from substrate type. Figure 9A shows that site 1, had its highest salinity $(\bar{x}=29.67 \pm 4.51$ ppt. $)$ at the middleward zone and the lowest $(\bar{x}=$ $26.33 \pm 2.99$ ppt.) at the landward zone. It also shows that this site had the lowest temperature $\left(\mathrm{x}=28.22 \pm 0.69^{\circ} \mathrm{C}\right)$ at the middleward zone and the highest $\left(\overline{\mathrm{x}}=30 \pm 1{ }^{\circ} \mathrm{C}\right)$ at the landward zone. A low temperature at the middleward zone could be attributed to the presence of dense mangrove vegetation in the zone. Meanwhile, the $\mathrm{pH}$ values in the site increased from the seaward zone up to the landward zone. The landward zone had the highest mean $\mathrm{pH}(\overline{\mathrm{x}}=8.44 \pm 0.51)$ among the other two zones. This zone is inhabited by the local community people that may have effects on the $\mathrm{pH}$ of the area. These three parameters did not significantly contribute to the density of $U$.perplexa per zone at $\alpha=0.05$. In the second site (Fig.9B), the highest salinity $(\overline{\mathrm{x}}=31.5 \pm 1.32 \mathrm{ppt}$.) was observed at the middleward zone while the lowest $(\bar{x}=30.83 \pm 1.44$ ppt.) at the landward zone. In terms of temperature variations in the different zones, it was observed that the lowest $(\overline{\mathrm{x}}=27.5 \pm 2.18$ $\left.{ }^{\circ} \mathrm{C}\right)$ was at the middleward zone and the highest $\left(\overline{\mathrm{x}}=29 \pm 1{ }^{\circ} \mathrm{C}\right)$ at the landward zone. The observed increase of temperature toward the landward zone of both sites could be due to the decline in number of mangrove species from the seaward to this zone (Fig. 9B). In this site, all of the three zones had the same $\mathrm{pH}$ value $(\overline{\mathrm{x}}=8.33 \pm 1.53)$ (Fig. 9B). Site 2 was vegetated and located away from human residences. However, these parameters did not also significantly contribute to the density of $U$. triangularis per zone at $\alpha=0.05$.

\section{CONCLUSION}

Results indicate that there are three fiddler crab species present in the mangrove area of Punta, Baybay City, Leyte namely, U. perplexa, U. triangularis, and U. crassipes. U. perplexa population dominated the unvegetated landward zone of the mangrove area. Individuals did not deviate from the typical 1:1 sex ratio. They also exhibited a non-normal overall size frequency distribution. Among the different sediment characteristics such as $\%$ organic carbon, matter, silt, clay and sand, it was the percent sand that influenced their population distribution. Individuals prefer substrates with high percent of sand with minimum portions of silt and clay. Salinity, temperature and $\mathrm{pH}$ had no influence on their density at a particular zone. On the other hand, U. triangularis was found in the three different zones of the mangrove area. The population had a lesser number of males as compared to the number of females, hence, deviated from the 1:1 sex ratio. The \% organic carbon, organic matter, silt, clay and sand did not influence the density of individuals in the different zones. Moreover, salinity, temperature and $\mathrm{pH}$ did not influence the density of individuals in the different zones of the mangrove area.

\section{ACKNOWLEDGMENT}

The authors would like to thank Ms. Cheryl C. Batistel and Dr. Analyn M. Mazo for the comments and suggestions which improved the manuscript.

\section{REFERENCES}

ACIOLE, S.D.G., E.C SOUSA and T.C.S. CALADO. 2000. Aspectos bioecológicos de Uca cumulanta Crane, 1943 and Uca leptodactyla Rathbun, 1898 (Crustacea: Decapoda: Ocypodidade) do complex estuarino-lagunar Mundaú/Manguaba - Maceió, Estado de Alagoas.Boletim de Estudos de Ciências do Mar. 79: 79-100.

BARTOLINI, F., G. PENHA-LOPES, S. LIMBU, J. PAULA and S. CANNICCI. 2009. Behavioral responses of the mangrove fiddler crabs (Uca annulipes and U. inversa) to urban sewage loadings: Result of a mesocosm approach. Marine Pollution Bulletin. 58: 1860-1867. 
BEZERRA, L.E.A., C. B. DIAS. G. X. SANTANA and H. M. CASCON. 2006. Spatial distribution of fiddler crabs (genus $U_{c a}$ ) in a tropical mangrove of northeast Brazil. Scientia Marina. 70:759-766.

BEZERRA, L.E.A. and H. M. CASCON. 2007. Population and reproductive biology of the fiddler crab Uca thayeri Rathbun, 1900 (Crustacea: Ocypodidae) in a tropical mangrove from Northeast Brazil. Acta oecologica. 31:70-71.

BORDEN, M.J. 2006. Comparative community structure of meiofauna in different mangrove zones of Punta, Baybay, Leyte. Unpublished B.S Thesis. Visayas State University, Visca, Baybay, Leyte. 15p.

BOTTO, F. and O. IRIBARNE. 2000. Contrasting effects of two burrow-ing crabs (Chasmagnathus granulate and Uca uruguayen-sis) on sediment composition and transport in estuarine environments. Estuar Coast Shelf Sci. 51:141-151.

CARMONA-SUAREZ, C. A. and J.E. CONDE. 1996. Littoral Brachyuran crabs (Crustacea: Decapoda) from Falcon, Venezuela, with biogeographical and ecological remarks. Review of Brasilian Biology. 56: 725-747.

COSTA, T.M., S.M.J. SILVA and M.L. NEGEIROS-FRANSOZO. 2006. Reproductive pattern comparison of Uca thayeri Rathbun, 1900 and U. uruguayensis Nobili, 1901 (Crustacea, Decapoda, Ocypodidae). Brazilian Archives of Biology and Technology. 49:117123.

CRANE, J. 1975. Fiddler Crabs of the World. Ocypodidae: Genus Uca. Princeton University Press, New Jersey. 125-126; 314; 324-325 pp.

CULBERTSON, J.B., I. VAHIELA, E.E. PEACOCK, C.M. REDDY, A. CARTER and R. VANDERKRUIK. 2007. Long-term biological effects of petroleum residues on fiddler crabs in salt marshes. Marine Pollution Bulletin. 54: 955-962.

GRIBSHOLT, P. M., J.E. KOSTKA and E. KRISTENSEN. 2003. Impact of fiddler crabs and plant roots on sediment biogeochemistry in a Georgia saltmarsh. Mar Ecol Prog Ser. 259:237-251.

JOHNSON, P.T.J. 2003. Biased sex ratios in fiddler crabs (Brachyura, Ocypodidae): a review and evaluation of the influence of sampling method, size class, and sexspecific mortality. Crustaceana. 76: 559-580.

KOGA, T., P.R.Y. BACKWELL, J.H. CHRISTY, M. MURAI and E. KASUYA. 2001. Male-biased predation of a fiddler crab. The association for the study of animal behavior. doi:10.1006/anbe.2001.1740

KRISTENSEN, E. and M. HOLMER. 2001. Decomposition of plant materials in marine sediment exposed to different electron acceptors $\left(\mathrm{O}_{2}, \mathrm{NO}_{3}{ }_{3}\right.$ and $\left.\mathrm{SO}_{4}{ }^{2}\right)$, with emphasis on substrate origin, degradation stage and the role of bioturbation. Geochimica Cosmochimica Acta (in press).

LEVINTON, J.S., C. STURMBAUER and J. CHRISTY. 1996. Molecular data and biogeography: resolution of the evolutionary history of a pantropical group of invertebrates. Journal of Experimental Marine Biology and Ecology. 203: 117- 131.

LITULO, C. 2005a. Population biology of the fiddler crab Uca annulipes (Brachyura: Ocypodidae) in a tropical East Africa mangrove (Mozambique). Estuar. Coast. Shelf Sci. 62: 283-290.

LITULO, C. 2005b. Population structure and reproductive biology of the fiddler crab Uca inversa (Hoffman, 1874) (Brachyura: Ocypodidae). Acta Oecol. 27: 135-141.

MACINTOSH, D. J. 1982. Ecological Comparison of Mangrove Swamp and Salt Marsh Fiddler Crabs. In: Gobal B, Turner RE, Wetzel RG, Whigham DF, editors. Wetlands Ecology and Management. Proceedings of the First International Wetlands Conference. pp. 243-257.

MOKHTARI, M., A. SAVARI, H. REZAI, P. KOCHANIAN and A. BITAAB. 2008. Population ecology of fiddler crab, Uca lactea annulipes (Decapoda: Ocypodidae) in Sirik mangrove estuary, Iran. Estuarine, Coastal and Shelf Science. 76:273- 281. 
MOKHTARI, M.M., A. GHAFFAR, G. USUP and Z.C. COB. 2015. Determination of Key Environmental Factors Responsible for Distribution Patterns of Fiddler Crabs in a Tropical Mangrove Ecosystem.PLoS ONE 10(1): e0117467. doi:10.1371 /journal.pone.0117467.

MONTAGUE, C. L. 1980. A natural history of temperate western Atlantic fiddler crabs (Genus $U_{c a}$ ) with reference to their impact on the salt marsh. Contrib. Mar. Sci. 23: 2555.

MONTES, H., S. CESAR, A. MAZO and E. DADOLE-ESPINOSA. 2009. Status of marine sanctuaries in Baybay City, Leyte: A report presented during the session of Sangguniang Panglungsod.

MOUTON, E. C. and D. L. FELDER. 1995. Reproduction of the fiddler crabs Uca longisignalis and Uca spinicarpa in a Gulf of Mexico salt marsh. Estuaries. 18: 469-481.

NOBBS, M. 1999. The behavioral ecology of fiddler crabs (Genus: Uca) that live in the mangrove forests of Darwin Harbour. Published Ph.d. Thesis. Northern Territory University. $7 \mathrm{p}$.

ROSENBERG, M.S. 2001. The systematics and taxonomy of fiddler crabs: a phylogeny of the genus Uca. Journal of Crustacean Biology. 21:839-869.

SPIVAK, E., M. A. GAVIO and C. E. NAVARRO. 1991. Life history and structure of the world's southernmost Uca population: Uca uruguayensis (Crustacea, Brachyura) in Mar Chiquita lagoon. Bulletin of Marine Science. 48: 679-688.

TAKEDA, S. and M. MURAI. 2003. Morphological and behavioural adaptations to the rocky substrate by the fiddler crab Uca panamensis (Stimpson, 1859): preference for feeding substratum and feeding mechanism. J. Exp. Mar. Biol. Ecol. 287: 179-191.

TALAPATRA, N., A. NANDY, K. BANERJEE, P. SANYAL and S. SWARNAKAR. 2014. Novel occurrence and relative abundance of fiddler crabs Uca lactea, Uca rosea and Uca annulipes at East coast of India. International Journal of Advanced Research. 2(10): 907-916.

THONGTHAM, N. and E. KRISTENSEN. 2003. Physical and chemical characteristics of mangrove crab (Neoepisesarma versicolor) burrows in the Bangrong mangrove forest, Phuket, Thailand; with emphasis on behavioural response to changing environmental conditions. Vie Milieu. 53:141-151.

WARREN, J.H. and A. J. UNDERWOOD. 1986. Effects of crabs on the topography of mangrove swamps in New South Wales. J. Exp. Mar. Biol. Ecol. 102: 223-235.

WOLF, M., V. KOCH and V. ISAAC. 2000. A trophic flow model of the Caete mangrove estuary (North Brazil) with consideration for the sustainable use of its resources. Estuarine, Coastal and Shelf Science. 50:789-803.

http://www.fiddlercrab.info/uca_systematics.html. Accessed on September 3, 2013. 